\title{
DOUBLE BLIND, RANDOMISED CONTROLLED STUDY FOR COMPARATIVE EVALUATION OF EQUAL VOLUME OF TWO DIFFERENT DOSES OF ROPIVACAINE HYDROCHLORIDE (0.75\% AND 0.5\%) IN SPINAL ANAESTHESIA IN LOWER LIMB ORTHOPAEDIC SURGERY REGARDING THE ONSET AND DURATION OF SENSORY AND MOTOR BLOCKADE
}

\author{
Shafaqat Rashid ${ }^{1}$, Suhail Vakil², Roshani Deshmukh³, Zameer Ali', Mehreen Rashid ${ }^{5}$, Nikhil Chamankar6, Swarn Gulati ${ }^{7}$ \\ ${ }^{1}$ Senior Resident, Department of Anaesthesiology and Critical Care, SKIMS Medical College, Srinagar, J and K, India. \\ ${ }^{2}$ Senior Resident, Department of Orthopaedics, SKIMS Medical College, Srinagar, J and K, India. \\ ${ }^{3}$ Senior Resident, Department of Anaesthesiology and Critical Care, TATA Memorial Hospital and Research Centre, Mumbai, India. \\ ${ }^{4}$ Senior Resident, Department of Orthopaedics, SKIMS Medical College, Srinagar, J and K, India. \\ ${ }^{5}$ Research Scholar, Alabama, USA. \\ ${ }^{6}$ Senior Resident, Department of General Surgery, Sir HN Reliance Hospital, Mumbai, India. \\ 7 Professor and Head, Department of Anaesthesiology and Critical Care, Amandeep Hospital, Amritsar, Punjab, India.
}

\section{ABSTRACT}

\section{BACKGROUND}

Central neuraxial blockade is a major regional anaesthesia technique with a long history of effective use for a variety of surgical procedures and pain relief. Ropivacaine is an amino-amide local anaesthetic drug, which was first synthesised in 1957 and was introduced into clinical practice in 1996. As there are limited studies on effect of ropivacaine in spinal anaesthesia, we conducted a dose comparison study of ropivacaine in our institute to know the clinical efficacy and safety with regard to better patient profile management.

The aim of the study was to compare and evaluate equal volumes of two different doses of ropivacaine hydrochloride $(0.75 \%$ and $0.5 \%$ ) in spinal anaesthesia in lower limb orthopaedic surgeries with regard to the onset and duration of sensory and motor blockade.

\section{MATERIALS AND METHODS}

It is a prospective, randomised, double-blind study conducted in a tertiary care hospital in which 80 patients of age group $20-65$ years of either sex which were scheduled to undergo lower limb orthopaedic surgeries under spinal anaesthesia with two different doses of Ropivacaine Hydrochloride were included. The patients were randomly divided into 2 groups of 40 each. Group A received $22.5 \mathrm{mg}(3 \mathrm{~mL})$ of $0.75 \%$ isobaric Ropivacaine Hydrochloride. Group B patients received $15 \mathrm{mg}(3 \mathrm{~mL})$ of $0.5 \%$ isobaric Ropivacaine Hydrochloride.

\section{RESULTS}

Ropivacaine $0.75 \%$ produced higher level and longer duration of sensory blockade than ropivacaine $0.5 \%$ when used in spinal anaesthesia. Thus, there was longer duration of analgesia with ropivacaine $0.75 \%$. The ropivacaine $0.75 \%$ solution resulted in higher frequency and longer duration of motor block in the lower limbs than ropivacaine $0.5 \%$. Thus, a reliable motor blockade was obtained with ropivacaine $0.75 \%$. Therefore, it is concluded that intrathecal ropivacaine $0.75 \%$ provides an excellent sensory blockade with longer duration of analgesia and a complete motor block, which makes it suitable for lower limb orthopaedic surgeries requiring an intense sensory and motor blockade.

\section{CONCLUSION}

Our study suggests the use of ropivacaine $0.75 \%$ for spinal anaesthesia in lower limb orthopaedic surgeries, as it provides prolonged duration of sensory and profound motor blockade of lower limbs.

\section{KEYWORDS}

Sensory Blockade, Motor Blockade, Ropivacaine, Spinal Anaesthesia, Lower Limb Surgery.

HOW TO CITE THIS ARTICLE: Rashid S, Vakil S, Deshmukh R, et al. Double blind, randomised controlled study for comparative evaluation of equal volume of two different doses of ropivacaine hydrochloride $(0.75 \%$ and $0.5 \%)$ in spinal anaesthesia in lower limb orthopaedic surgery regarding the onset and duration of sensory and motor blockade. J. Evolution Med. Dent. Sci. 2017;6(58): 4321-4326, DOI: $10.14260 / J e m d s / 2017 / 934$

\section{BACKGROUND}

Central neuraxial blockade is a major regional anaesthesia technique with a long history of effective use for a variety of

Financial or Other, Competing Interest: None.

Submission 26-04-2017, Peer Review 08-07-2017,

Acceptance 14-07-2017, Published 20-07-2017.

Corresponding Author:

Dr. Shafaqat Rashid,

R/O: B-12, Budshah Nagar,

Natipora, Srinagar-190015,

Jammu \& Kashmir, India.

E-mail: shafu2400542@yahoo.co.in

DOI: $10.14260 /$ jemds $/ 2017 / 934$ surgical procedures and pain relief as quoted from Gupta P et al.[1] Ropivacaine is an amino-amide local anaesthetic drug, which was first synthesised in $1957^{[2]}$ and was introduced into clinical practice in 1996 and has consistently demonstrated an improved safety profile over bupivacaine with a reduced CNS and cardiotoxic potential.[3] It has low lipid solubility, which blocks nerve fibres involved in pain transmission (A delta and $\mathrm{C}$ fibres) to a greater degree than those controlling motor functions (A beta fibres).[4] Ropivacaine was used in epidural anaesthesia in lower extremity surgery where it was compared with bupivacaine by Brown DL and colleagues in 1990. They concluded that 
ropivacaine produced similar sensory and motor blockade with less cardiotoxicity.[5] Intrathecal administration of ropivacaine is useful for ambulatory anaesthesia, as there is fast regression of motor block which causes early mobilisation and recovery.[6] As there are limited studies on effect of ropivacaine in spinal anaesthesia, so we conducted a dose comparison study of ropivacaine in our institute to know the clinical efficacy and safety of two different doses $(0.5 \%$ and $0.75 \%)$ of ropivacaine in patients undergoing lower limb orthopaedic surgery under spinal anaesthesia presuming that higher dose of the drug causes better patient profile management. The aim of the study was to compare and evaluate equal volumes of two different doses of ropivacaine hydrochloride $(0.75 \%$ and $0.5 \%)$ in spinal anaesthesia in lower limb orthopaedic surgeries with regard to the onset and duration of sensory and motor blockade. The primary outcome of the study was to assess the onset and duration of sensory and motor block and the secondary outcome of the study were haemodynamic changes and complications.

\section{MATERIALS AND METHODS}

It is a prospective, randomised double-blind study in which 80 patients of American Society of Anesthesiologists (ASA) physical status I and II of age group 20-65 years of either sex was admitted in a tertiary care super speciality hospital over a span of 2.5 years from August 2011 to February 2014.

\section{Inclusion Criteria}

Patients who were scheduled to undergo lower limb orthopaedic surgeries under spinal anaesthesia were included after the approval of Ethical and Scientific Committee of the Institution along with the informed written consent from the patients.

\section{Exclusion Criteria}

The type of patients excluded from the study were unwillingness of the patient, any life-threatening disease, neurological disorders, coagulation disorders, morbid obesity, any signs of sepsis, deformity or previous surgery of spine, any anticipated difficulty in regional anaesthesia, any history of allergy to study drug and infection at injection site.

\section{Sample Size}

From the previous study by Veena et al, the mean time for two-dermatome regression has been reported in the range of 112 to 131 minutes with a populated standard deviation (sigma) of 29 minutes.[7] This parameter was selected as it could be the earliest indicator of fading effect of anaesthesia. For $95 \%$ confidence interval and $80 \%$ power of the study 37 patients would be needed in each group using following formula-

$$
\mathrm{N}=\frac{2\left[(a+b)^{2} \sigma^{2}\right]}{(\mu 1-\mu 2)^{2}}
$$

where, $\mathrm{a}$ and $\mathrm{b}$ are $\mathrm{a}=$ conventional multiplier for alpha $=$ $0.05, \mathrm{~b}=$ conventional multiplier for power $=0.80, \mu 1-\mu 2=$ the difference between the means from the previous study (131 - 112 minutes), $\sigma^{2}$ is populated standard deviation (29 minutes). To allow for dropouts, sample size was fixed at 40 patients in each group.

\section{Study Protocol}

Pre-anaesthetic assessment was carried out in every case one day before surgery. All the patients were given Tab. Alprazolam $0.25 \mathrm{mg}$ a night before surgery in the orthopaedic ward. Inj. Midazolam $0.04 \mathrm{mg} / \mathrm{kg}$ body weight was given by intravenous route just before procedure in all the groups in the operating room.

A total of 86 patients met the inclusion criteria and were included in the study. Patients were randomly divided into two groups in a double-blind manner. In the operating room, patients were randomised by sealed envelope method (wherein, externally computer-generated numbers were used) to the groups. The randomisation code allotted to the patients was kept separately and investigators were blinded to it until the study was completed. Different concentrations $(0.75 \%$ and $0.5 \%)$ isobaric ropivacaine hydrochloride were covered with opaque sacks by the pharmacist in the 1:1 ratio. Only the pharmacist was aware of the code given to the type of solution in the vials. This ensured the double blinding.

Out of 86 patients who met the inclusion and exclusion criteria, 6 patient's procedure was converted to general anaesthesia due to orthopaedic problems. These 6 patients were not considered for analysis.

Standard proforma was made for all the patients. Group A (40 patients) received $22.5 \mathrm{mg}(3 \mathrm{~mL})$ of $0.75 \%$ isobaric ropivacaine hydrochloride. Group B (40 patients) received 15 $\mathrm{mg}(3 \mathrm{~mL}$ ) of $0.5 \%$ isobaric ropivacaine hydrochloride.

Multiparameter monitor was applied and baseline heart rate, non-invasive blood pressure, respiratory rate, oxygen saturation and ECG were recorded on the concerned proforma. Intravenous line was secured with 18-G intracath and the patients were preloaded with $10 \mathrm{~mL} / \mathrm{kg}$ body weight of ringer lactate over 15 - 20 mins. The patients were placed in the lateral decubitus position with the affected limb in the dependent position. Spinal anaesthesia was administered with 26-G Quincke's spinal needle using the standard midline approach at L2 - L3 interspace. The position of the needle was confirmed by free flow of cerebrospinal fluid. Then $3 \mathrm{~mL}$ of the study drug was injected into the subarachnoid space. After administration of study drug, the patient was immediately turned to the supine horizontal position.

Sensory block was assessed by loss of sensation to pin prick in the mid-clavicular line starting from caudad and moving cephalad using 27-G short bevel needle. In both Groups A and B sensory blockade was assessed every 2 minutes post injection for first 10 minutes, then every 5 minutes for next 30 minutes and then every 15 minutes for next 180 minutes and then every 30 minutes till normal sensation returned by pinprick method. The sensory parameters noted were onset of sensory blockade at T10, maximum level of sensory block, time to regression to T10, L5 and S1 and total duration of sensory blockade (time to regression to S1). Motor blockade was checked according to modified Bromage scale.[8,9] Motor blockade was also assessed immediately after the assessment of sensory block until the return of normal motor function. The parameters noted were time of onset of motor block, maximum grade of motor block achieved and total duration of motor block.

Oxygen was routinely administered via oxygen mask at oxygen flow rate of $5 \mathrm{~L} / \mathrm{min}$. Bradycardia (defined as heart rate less than $60 \mathrm{bpm}$ ) was treated with $0.6 \mathrm{mg}$ diluted intravenous Atropine. Hypotension (defined as systolic blood 
pressure less than $100 \mathrm{mmHg}$ or $30 \%$ less than the base value) was treated with IV mephentermine (diluted- $30 \mathrm{mg}$ in incremental doses) with additional ringer lactate solution. The operation was started when full surgical anaesthesia developed. In case of failed neuraxial blockade, where patients required general anaesthesia were excluded from the study. Continuous multipara monitoring (respiratory rate, pulse rate, non-invasive blood pressure, oxygen saturation, ECG) was done and readings were recorded. Patients were monitored for side-effects and complications during intraoperative period and next 24 hours after the operation and measures to combat them were kept ready beforehand.

Statistical analyses were performed using the SPSS (Statistical Package for the Social Science System version SPSS 17.0 Chicago SPSS Inc.) version 17.0 program for Windows. We conducted a Shapiro-Wilk test to verify the distribution of the data. All data were summarised as the mean \pm SD.

Onset of sensory block at $\mathrm{T} 10$, time taken to reach maximum level of sensory blockade and time taken to regress, time to complete motor block and total duration of motor block, mean pulse rate, mean systolic and diastolic blood pressures, time for analgesia and total duration of surgery was compared using student t-test. Maximum level of sensory block (expressed as frequency of occurrences at T6, T8 and T10) and maximum grade of motor block were compared using Chi square test. Values less than 0.05 were considered significant.

\section{RESULTS}

\begin{tabular}{|c|c|c|c|c|c|}
\hline $\begin{array}{c}\text { Demographic } \\
\text { Parameters }\end{array}$ & $\begin{array}{c}\text { Group } \\
\text { A }\end{array}$ & $\begin{array}{c}\text { Group } \\
\text { A }\end{array}$ & $\begin{array}{c}\text { Group } \\
\text { B }\end{array}$ & $\begin{array}{c}\text { Group } \\
\text { B }\end{array}$ & \\
\hline & $\begin{array}{c}\text { Mean +/- } \\
\text { SD }\end{array}$ & $\begin{array}{c}\text { Min - } \\
\text { Max }\end{array}$ & $\begin{array}{c}\text { Mean +/- } \\
\text { SD }\end{array}$ & $\begin{array}{c}\text { Min - } \\
\text { Max }\end{array}$ & $\begin{array}{c}\text { P } \\
\text { value }\end{array}$ \\
\hline $\begin{array}{c}\text { Age } \\
\text { (Years) }\end{array}$ & $\begin{array}{c}40.60 \pm \\
7.85\end{array}$ & $33-48$ & $\begin{array}{c}38.85 \pm \\
7.75\end{array}$ & $31-47$ & 0.319 \\
\hline $\begin{array}{c}\text { Weight } \\
\text { (kgs) }\end{array}$ & $\begin{array}{c}64.67 \pm \\
4.28\end{array}$ & $52-70$ & $\begin{array}{c}63.43 \pm \\
4.83\end{array}$ & $50-70$ & 0.225 \\
\hline $\begin{array}{c}\text { Sex } \\
\text { (Female/ } \\
\text { Male) }\end{array}$ & $13 / 27$ & NA & $16 / 24$ & NA & 0.642 \\
\hline $\begin{array}{c}\text { ASA Grade } \\
\text { (I/II) }\end{array}$ & $28 / 12$ & NA & $31 / 9$ & NA & 0.446 \\
\hline \multicolumn{7}{|c|}{ Table 1. Demographic Parameters } \\
\hline
\end{tabular}

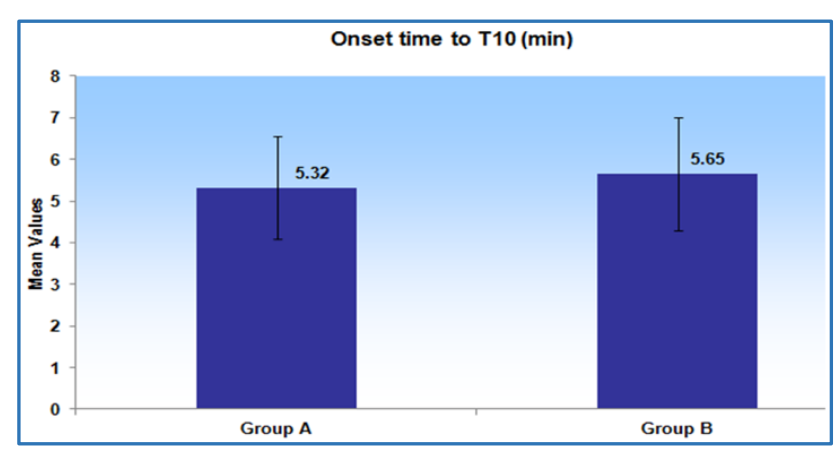

Figure 1. Onset of Sensory Block to T-10 Dermatome

\begin{tabular}{|c|c|c|c|c|c|}
\hline $\begin{array}{c}\text { Maximum } \\
\text { Sensory } \\
\text { Level }\end{array}$ & $\begin{array}{c}\text { Group } \\
\text { A }\end{array}$ & & $\begin{array}{c}\text { Group } \\
\text { B }\end{array}$ & & $\begin{array}{c}P \\
\text { Value }\end{array}$ \\
\hline & Frequency & $\begin{array}{c}\text { Group } \\
\text { A }\end{array}$ & Frequency & $\begin{array}{c}\text { Group } \\
\text { B }\end{array}$ & \\
\hline T6 & 15 & $37.5 \%$ & 7 & $17.5 \%$ & \multirow{4}{*}{0.039} \\
\hline T8 & 20 & $50 \%$ & 20 & $50 \%$ & \\
\hline T10 & 5 & $12.5 \%$ & 13 & $32.5 \%$ & \\
\hline Total & 40 & $100 \%$ & 40 & $100 \%$ & \\
\hline \multicolumn{6}{|c|}{ Table 2. Maximum Level of Sensory Block Achieved } \\
\hline
\end{tabular}

\begin{tabular}{|c|c|c|c|c|c|}
\hline & \multicolumn{2}{|c|}{ Group A $(n=40)$} & \multicolumn{2}{|c|}{ Group B $(n=40)$} & \multirow[b]{2}{*}{ P Value } \\
\hline & Mean \pm SD & $\begin{array}{l}\text { Min- } \\
\text { Max }\end{array}$ & $\begin{array}{c}\text { Mean } \pm \\
\text { SD }\end{array}$ & $\begin{array}{l}\text { Min- } \\
\text { Max }\end{array}$ & \\
\hline $\begin{array}{c}\text { Time to } \\
\text { maximum } \\
\text { level (mins) }\end{array}$ & $7.55 \pm 1.59$ & $\begin{array}{l}4- \\
10\end{array}$ & $\begin{array}{c}7.85 \pm \\
1.78\end{array}$ & $\begin{array}{l}4- \\
12\end{array}$ & 0.430 \\
\hline $\begin{array}{l}\text { Time to two } \\
\text { dermatome } \\
\text { regression }\end{array}$ & $\begin{array}{c}126.50 \pm \\
14.42\end{array}$ & $\begin{array}{c}100- \\
150\end{array}$ & $\begin{array}{c}96.50 \pm \\
10.33\end{array}$ & $\begin{array}{l}70- \\
114\end{array}$ & $<0.001$ \\
\hline $\begin{array}{l}\text { Time to } \\
\text { regression } \\
\text { to } \mathrm{T}-10\end{array}$ & $\begin{array}{c}138.57 \pm \\
22.11\end{array}$ & $\begin{array}{c}100- \\
180\end{array}$ & $\begin{array}{c}105.33 \pm \\
16.96\end{array}$ & $\begin{array}{l}70- \\
140\end{array}$ & $<0.001$ \\
\hline $\begin{array}{l}\text { Time to } \\
\text { regression } \\
\text { to L5 }\end{array}$ & $\begin{array}{c}166.75 \pm \\
22.12\end{array}$ & $\begin{array}{c}130- \\
210\end{array}$ & $\begin{array}{c}124.75 \pm \\
15.36\end{array}$ & $\begin{array}{c}100- \\
160\end{array}$ & $<0.001$ \\
\hline $\begin{array}{l}\text { Time to } \\
\text { regression } \\
\text { to } S 1\end{array}$ & $\begin{array}{c}193.50 \pm \\
21.90\end{array}$ & $\begin{array}{c}150- \\
230\end{array}$ & $\begin{array}{c}146.00 \pm \\
15.82\end{array}$ & $\begin{array}{c}120- \\
180\end{array}$ & $<0.001$ \\
\hline
\end{tabular}

Table 3. Time taken to reach Maximum Level of Sensory Blockade and Time taken to Regress to T-10, L5, S1

\begin{tabular}{|c|c|c|c|c|c|}
\hline & \multicolumn{2}{|c|}{ Group A (n $=40)$} & \multicolumn{2}{|c|}{ Group B $(n=40)$} & \multirow{2}{*}{$\begin{array}{c}P \\
\text { Value }\end{array}$} \\
\hline & $\begin{array}{c}\text { Mean } \pm \\
\text { SD }\end{array}$ & $\begin{array}{c}\text { Min - } \\
\text { Max }\end{array}$ & \begin{tabular}{|c|} 
Mean \pm \\
SD
\end{tabular} & $\begin{array}{l}\text { Min- } \\
\text { Max }\end{array}$ & \\
\hline $\begin{array}{c}\text { Time to } \\
\text { Complete } \\
\text { Block (mins) }\end{array}$ & $\begin{array}{c}9.73 \pm \\
1.85\end{array}$ & $8-15$ & $\begin{array}{c}9.85 \pm \\
1.59\end{array}$ & $\begin{array}{l}6- \\
14\end{array}$ & 0.747 \\
\hline $\begin{array}{c}\text { Total duration } \\
\text { of Motor } \\
\text { Block (mins) }\end{array}$ & $\begin{array}{c}190.50 \pm \\
21.60\end{array}$ & $\begin{array}{c}150- \\
230\end{array}$ & $\begin{array}{r}137.50 \\
\pm 15.65\end{array}$ & $\begin{array}{c}100- \\
170\end{array}$ & $<0.001$ \\
\hline \multicolumn{6}{|c|}{ Table 4. Time to Complete Motor } \\
\hline
\end{tabular}

\begin{tabular}{|c|c|c|c|c|c|}
\hline $\begin{array}{c}\text { Maximum } \\
\text { Grade } \\
\text { of Motor } \\
\text { Block }\end{array}$ & $\begin{array}{c}\text { Group } \\
\text { A }\end{array}$ & & $\begin{array}{c}\text { Group } \\
\text { B }\end{array}$ & & $\begin{array}{c}P \\
\text { Value }\end{array}$ \\
\hline & Frequency & $\begin{array}{c}\text { Group } \\
\text { A }\end{array}$ & Frequency & $\begin{array}{c}\text { Group } \\
\text { B }\end{array}$ & \\
\hline II & 5 & $12.5 \%$ & 17 & $42.5 \%$ & \multirow{3}{*}{0.003} \\
\hline III & 35 & $87.5 \%$ & 23 & $57.5 \%$ & \\
\hline Total & 40 & $100 \%$ & 40 & $100 \%$ & \\
\hline \multicolumn{6}{|c|}{ Table 5. Maximum Grade of Motor Block } \\
\hline
\end{tabular}




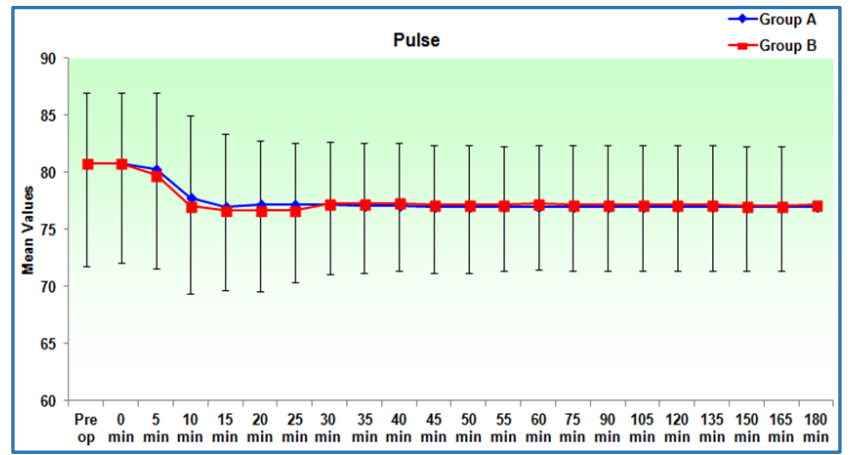

Figure 2. Mean Pulse Rate (minutes) from Pre-operative Period till 180 Minutes

\section{Systolic and Diastolic Blood Pressure}

The mean systolic blood pressure in the pre-operative period at the time of spinal anaesthesia ( 0 minutes), then at an interval of 5 minutes for first 60 minutes and then at an interval of 15 minutes till 180 minutes was found to be statistically insignificant in both the groups. The mean diastolic blood pressure in pre-operative period at the time of spinal anaesthesia, then at an interval of 5 minutes till 60 minutes of spinal anaesthesia and then at an interval of 15 minutes till 180 minutes was comparable in both the groups and statistically was found to be insignificant $(p>0.05)$.

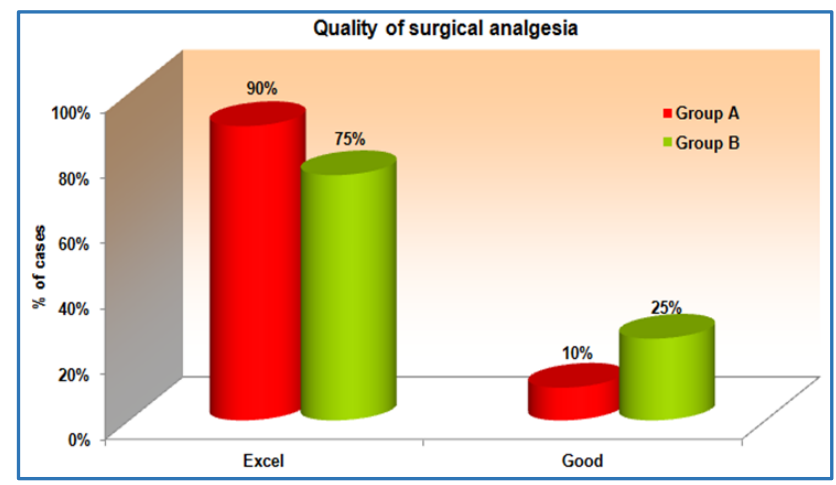

Figure 3. Quality of Surgical Analgesia

\begin{tabular}{|c|c|c|c|c|c|}
\hline & \multicolumn{2}{|c|}{ Group A $(n=40)$} & \multicolumn{2}{|c|}{ Group B (n $=40)$} & \multirow[b]{2}{*}{$\begin{array}{c}P \\
\text { Value }\end{array}$} \\
\hline & $\begin{array}{l}\text { Mean } \pm \\
\text { SD }\end{array}$ & $\begin{array}{l}\text { Min- } \\
\text { Max }\end{array}$ & $\begin{array}{c}\text { Mean } \pm \\
\text { SD }\end{array}$ & $\begin{array}{l}\text { Min - } \\
\text { Max }\end{array}$ & \\
\hline $\begin{array}{l}\text { Time of } \\
\text { analgesia } \\
\text { request } \\
\text { (min) }\end{array}$ & $\begin{array}{c}322.5 \pm \\
32.01\end{array}$ & $\begin{array}{c}220- \\
400\end{array}$ & $\begin{array}{l}210 \pm \\
14.68\end{array}$ & $\begin{array}{c}180- \\
230\end{array}$ & $<0.001$ \\
\hline $\begin{array}{c}\text { Duration } \\
\text { of surgery } \\
\text { (min) }\end{array}$ & $\begin{array}{l}84.5 \pm \\
10.05\end{array}$ & $\begin{array}{l}70- \\
100\end{array}$ & $\begin{array}{l}82.4 \pm \\
10.26\end{array}$ & $\begin{array}{l}60- \\
100\end{array}$ & 0.358 \\
\hline
\end{tabular}

\section{DISCUSSION}

Both the groups were comparable with regard to age, sex, weight, ASA physical status and duration of surgery. In our study, onset of sensory block to T10 dermatome of patients in Group A receiving ropivacaine $0.75 \%$ was similar to that of Group B receiving ropivacaine $0.5 \%$ for spinal anaesthesia (Fig. 1). Similar results were shown by Van Kleef et al in his study, where he compared ropivacaine $0.75 \%$ and $0.5 \%$ for spinal anaesthesia in lower limb orthopaedic surgery.[10] As depicted in Table 2 in our study 15 patients in Group A had the highest level of sensory blockade to T6, whereas only 7 patients in Group B had T6 as the highest level of sensory blockade. 20 patients in each group had T8 as maximum level of sensory blockade. The difference in the highest level of sensory block was found to be statistically significant between the two groups. Ropivacaine $0.75 \%$ produced higher level of sensory blockade than $0.5 \%$ ropivacaine. However, results were contrary to the study done by Van Kleef et al which showed extremely variable analgesic spread with both the concentrations and was statistically insignificant.[10] This variation in results could be due to differences in methodology between the studies that make accurate comparisons difficult. In the same study, patients were placed in sitting position for spinal anaesthesia and it was given at the L3-L4 interspace, whereas in our study the procedure was performed at the level of L2-L3 level in the lateral decubitus position. In another study done by Wahedi et al, it was found that the mean cephalad extent of anaesthesia increased with increasing the concentration of ropivacaine, T10 with $15 \mathrm{mg}$ and T8 with $22.5 \mathrm{mg}$ of ropivacaine.[11] In this study patients were placed in sitting position for spinal anaesthesia, which was given at L3-L4 interspace and spread and regression of sensory block was assessed by testing loss of sensation to cold. Whereas, in our study we have assessed spread and regression of sensory block by testing loss of sensation to a pin prick. The time taken to reach the maximum level of sensory blockade was similar in both the groups.

As shown in Table 3, the time for two dermatome regression was significantly greater in patients receiving $0.75 \%$ ropivacaine $(126.50 \pm 14.42$ minutes $)$ than in patients receiving $0.5 \%$ ropivacaine $(96.50 \pm 10.33$ minutes). The time for regression to T10 dermatome in patients receiving $0.75 \%$ ropivacaine was significantly greater (138.57 \pm 22.11 minutes) than in patients receiving $0.5 \%$ ropivacaine $(105.33$ \pm 16.96 minutes). The total duration of sensory blockade (time to regression to S1 dermatome) was significantly greater in patients receiving $0.75 \%$ ropivacaine $(193.50 \pm$ 21.90 minutes) than the patients receiving $0.5 \%$ ropivacaine (146 \pm 15.82 minutes). This was in accordance with the studies,[10,11] which showed that the ropivacaine $0.75 \%$ had longer mean duration of sensory blockade than ropivacaine $0.5 \%$.

Motor block was assessed using modified Bromage scale. ${ }^{[8,9]}$ In our study, the time taken for total motor blockade was similar in both the groups (Table 4 and 5). All the patients achieved motor block of at least Grade I on modified Bromage scale. Only 5 patients in Group A had Grade II motor block, whereas 17 patients in Group B had Grade II motor blockade; 35 patients in Group A had Grade III motor block, whereas only 23 patients had Grade III motor block in Group B. The difference was found to be statistically significant. Our study indicated that ropivacaine $0.75 \%$ produced significantly longer duration of profound motor blockade $(190.50 \pm 21.60$ minutes) than ropivacaine $0.5 \%$ (137.50 \pm 15.65 minutes). The results were consistent with the study done by Van Kleef et al, which showed that intrathecal $0.75 \%$ ropivacaine solution resulted in a higher frequency of complete motor block and longer duration of motor block in the lower limbs.[10] In a study by McNamee et al, patients were randomised to receive either $2.5 \mathrm{~mL}$ of ropivacaine $0.75 \%$ or $2.5 \mathrm{~mL}$ of ropivacaine $1 \%$ in spinal anaesthesia for 
total hip arthroplasty. The study depicted that increase in the dose of intrathecal ropivacaine administered led to an increased duration of profound motor block.[12] However, in another study done by McClellard et al, patients were randomised to receive intrathecal injection of either $3.5 \mathrm{~mL}$ of isobaric ropivacaine $0.5 \%$ or $3.5 \mathrm{~mL}$ of $0.5 \%$ isobaric bupivacaine. It was seen that median duration of complete motor blockade was significantly shorter in the ropivacaine group compared to bupivacaine group.[13] The lesser motor blockade of ropivacaine as compared to equal dose of bupivacaine can be explained by its lesser lipid solubility and myelin sheath penetration, thereby causing selective action on A-delta and C fibres that carry pain rather than A-beta fibres which are involved in motor function. ${ }^{[4]}$ This greater degree of differential block with ropivacaine at low concentrations has a clinical advantage in providing analgesia with minimal motor block, especially when early ambulation is desirable. However, in our study ropivacaine $0.75 \%$ provides complete motor blockade, which makes it suitable for lower limb orthopaedic surgeries where intense motor blockade is needed and where early ambulation is not a consideration.

The difference in mean pulse rate measured at various intervals intra-operatively and post-operatively was found to be statistically insignificant between the two groups (Fig. 2). Only 5 patients receiving ropivacaine $0.75 \%$ and 3 patients receiving $0.5 \%$ ropivacaine had bradycardia during first 60 minutes which was treated with intravenous injection atropine $0.6 \mathrm{mg}$ (diluted). The difference in the mean systolic and diastolic blood pressure measured at various intervals intra-operatively and post-operatively was found to be statistically insignificant between the two groups. Only 7 patients receiving ropivacaine $0.75 \%$ and 6 patients receiving ropivacaine $0.5 \%$ developed hypotension (systolic blood pressure below $100 \mathrm{mmHg}$ or below $30 \%$ of baseline) during first 60 minutes which was treated with Inj. mephentermine (diluted) and intravenous fluid-lactated ringer. In terms of safety, both doses of intrathecal ropivacaine provided high degree of cardiovascular stability with a low incidence of bradycardia and hypotension. The results correspond with other studies. ${ }^{[10,11,12]}$ in which it was found that there was high degree of cardiovascular safety and there was no difference in various groups receiving different doses of ropivacaine.

The time to first request for analgesia after spinal blockade was noted post-operatively. The mean time of analgesia request in patients receiving ropivacaine $0.75 \%$ was significantly more $(322 \pm 32.01$ minutes $)$ than the patients receiving ropivacaine $0.5 \%$ (210 \pm 14.68 minutes $)$, as there was significantly prolonged duration of sensory analgesia in patients receiving intrathecal ropivacaine $0.75 \%$ than patients receiving ropivacaine $0.5 \%$ (Table 6). The above results were in accordance with various studies, $[10,11,12]$ which demonstrated prolonged sensory analgesia with intrathecal $0.75 \%$ ropivacaine than with $0.5 \%$ ropivacaine.

In terms of safety, both doses of intrathecal ropivacaine provided a high degree of cardiovascular stability with a low incidence of bradycardia and hypotension. Only 5 patients in Group A (ropivacaine $0.75 \%$ ) and 3 patients in Group B (ropivacaine $0.5 \%$ ) had bradycardia intra-operatively. Only 7 patients in Group A and 6 patients in Group B developed hypotension. It was statistically insignificant, which was well in accordance with the various studies found in literature.[10,11,12] In our study only 5 patients out of 80 patients had post dural puncture headache, which was managed with intravenous fluids and a non-steroidal antiinflammatory drug. It was in accordance with the study done by Wahedi et al, in which 12 out of 40 patients had post dural puncture headache and was statistically insignificant.[11] In another study by Kallio et al in which hyperbaric and plain ropivacaine $15 \mathrm{mg}$ were compared in spinal anaesthesia in lower limb orthopaedic study, only 5 patients out of 56 patients had post dural puncture headache.[14] There is no study indicating that the incidence of post dural puncture headache is drug related.[3] In our study, only 8 patients in Group A and 6 groups in Group B had nausea and vomiting intra-operatively and post-operatively. Nausea and vomiting intra-operatively might have occurred due to concurrent hypotension whereas post-operatively, nausea and vomiting possibly could be due to Inj. Tramadol. Our study was in accordance with various studies[10,12] who also found insignificant changes with respect to nausea and vomiting. There was no case of local anaesthetic toxicity, pruritis or total spinal in both the groups. There was no case of neurological deficit in both the groups. There was no case of backache or urinary retention in both the groups during first 24 hours after surgery.

\section{CONCLUSION}

Ropivacaine $0.75 \%$ produced higher level of sensory blockade and longer duration of sensory blockade than ropivacaine $0.5 \%$ when used in spinal anaesthesia. Thus, there was longer duration of analgesia with ropivacaine $0.75 \%$. The ropivacaine $0.75 \%$ solution resulted in higher frequency of complete motor block and longer duration of motor block in the lower limbs than ropivacaine $0.5 \%$. Thus, a reliable motor blockade was obtained with ropivacaine $0.75 \%$. Therefore, it is concluded that intrathecal ropivacaine $0.75 \%$ provides an excellent sensory blockade and complete motor blockade with longer duration of analgesia and motor block, which makes it suitable for lower limb orthopaedic surgeries requiring an intense sensory and motor blockade. It is a well-tolerated regional anaesthetic effective for surgical anaesthesia.

Our study suggests the use of ropivacaine $0.75 \%$ for spinal anaesthesia in lower limb orthopaedic surgeries, as it provides prolonged duration of sensory and profound motor blockade of lower limbs.

\section{REFERENCES}

[1] Gupta P, Dua CK, Verma UC, et al. Sequential combined spinal epidural versus epidural anaesthesia in orthopaedic and gynaecological surgery: a comparative evaluation. Ind J Anaesth 2002;46(6):453-6.

[2] McClure JH. Ropivacaine. British J Anaesthesia 1996;76:300-7.

[3] Wille M. Intrathecal use of Ropivacaine: a review. Acta Anaesth Belg 2004;55(3):251-9.

[4] Akerman B, Hellberg IB, Trossvik C. Primary evaluation of the local anaesthetic properties of the amino amide agent Ropivacaine (LEA 103). Acta Anaesth Scand 1988;32(7):571-8. 
[5] Brown DL, Carpenter RL, Thompson GE. Comparison of $0.5 \%$ Bupivacaine for epidural anaesthesia in patients undergoing lower-extremity surgery. Anesthesiol 1990;72(4):633-6.

[6] Hansen TG. Ropivacaine: a pharmacological review. Expert Rev 2004;4(5):781-91.

[7] Chatrath V, Sharan R, Kheterpal R, et al. Comparative evaluation of $0.75 \%$ ropivacaine with clonidine and $0.5 \%$ bupivacaine with clonidine in infraclavicular brachial plexus block. Anesth Essays Res 2015;9(2):189-94.

[8] Breen TW, Shapiro T, Glass B, et al. Epidural anesthesia for labor in the ambulatory patient. Anesth Analg 1993;77(5):919-24.

[9] Bromage PR. A comparison of the hydrochloride and carbon dioxide salts of lidocaine and prilocaine in epidural analgesia. Acta Anaesth Scand Suppl 1965;16:55-69.
[10] van Kleef JW, Veering BT, Burm AGL. Spinal anaesthesia with Ropivacaine: a double blind study on the efficacy and safety of $0.5 \%$ and $0.75 \%$ solution in patients undergoing minor lower limb surgery. Anaesth Analgesia 1994;78(6):1125-30.

[11] Wahedi W, Nolte H, Klein P. Ropivacaine in spinal anaesthesia: a dose finding study. Anaesthetist 1996;45(8):737-44.

[12] McNamee DA, Parks L, McClelland AM, et al. Intrathecal ropivacaine for total hip arthoplasty: double blind comparative study with isobaric $7.5 \mathrm{mg}$ $\mathrm{ml}(-1)$ and $10 \mathrm{mg} \operatorname{ml}(-1)$ solutions. British J Anaesthesia 2001;87(5):743-7.

[13] McClellard A, McNamee D, Scott S, et al. A double blind comparison of ropivacaine $5 \mathrm{mg} / \mathrm{ml}$ and bupivacaine $5 \mathrm{mg} / \mathrm{ml}$ for intrathecal anaesthesia in major orthopaedic surgery (Total hip Arthoplasty). British J Anaesthesia 2002;89:702-6.

[14] Kallio H, Snall EVT, Tuomas CA, et al. Comparison of hyperbaric and plain ropivacaine $15 \mathrm{mg}$ in spinal anaesthesia for lower limb surgery. British J Anaesthesia 2004;93(5):664-9. 